\title{
DIE BOEK PREDIKER: 'N SMARTKREET OM DIE GEVALLE MENS*
}

PROF. DR. J. P. OBERHOLZER.

„En buitendien, my seun, wees gewaarsku, aan baie boeke mak kom geen einde nie en baie studie is vermoeiing van die vlees." (Pred. 12:12).

Hierdie woorde is afkomstig van 'n wyse uit die ou tyd. Daar bestaan twyfel of die woorde van die Prediker self afkomstig is. Daar is baie geleerdes wat aanvaar dat dit 'n ander wyse is wat op 'n sekere stadium hierdie woorde agter in die Prediker se boek ingeskryf het en dat dié ander wyse eintlik daarmee kommentaar wou lewer op die inhoud van die Prediker se boek. Hy wil dan eintlik sy leerlinge waarsku om nie die Prediker se bevindinge oor die groot lewensvrae al te ernstig te neem nie. Dieselfde wyse wat dan daardie opmerking sou bygevoeg het, of 'n ander wyse, het daarna nog 'n opmerking bygevoeg waarin hy sê dat die hoofsom van wat gehoor is, dit is dat die mens God vrees en Sy gebooie onderhou, waarmee hy eintlik wil te kenne gee dat die mens sy heelheid alleen vind in die verhouding tot God. En hy sluit dit dan af met die versekering: „God sal elke werk bring in die gerig wat kom ..."

Vir ons doel maak dit nie baie saak of dié betrokke woorde van die Prediker self afkomstig is of van iemand anders nie. Wat ons betref, as lede van die kerk van Christus, is dit deel van die boek Prediker, een van die Kanonieke Boeke van die Heilige Skrif waarvan ons in ons Belydenisskrifte sê dat dit die norm en die reël van die Christelike geloof is.

In ieder geval moet ons verklaar dat die klimaat van daardie woorde volkome aanpas by die inhoud van die Prediker se boek. Baie boeke maak is soos al die moeitevolle arbeid van die mens. Daar is geen einde aan nie. En daarop vorm die geleerde arbeid geen uitsondering nie. Dit is nie 'n stille eiland waar die dae lank en rustig is te midde van die groot storms van die lewe nie, dit is nie 'n oase waar die vrugte daar is vir die pluk te midde van 'n groot en onvrugbare woestyn nie. Die oorgawe aan die studie, die toewyding deur waarneming en konklusie is nie anders as die ander menslike werksaamhede nie. Dit is ' $n$ vermoeiing van die vlees. "Al die dinge is so vermoeiend", sê die Prediker aan die begin van sy boek, „die oog kry nie genoeg van sien nie en

\footnotetext{
- Intreepreek ter aanvaarding van die amp van hoogleraar in die Ou Testamentiese Wetenskap vanweë die Ned. Hervormde Kerk aan die Universiteit van Pretoria, gehou te Pretoria op 17 Maart 1971.
} 
dic oor word nie vol van hoor nie". Dwarsdeur sy bosk klink soos kluite op 'n kis die bevinding van die Prediker oor die werk waarmee die mens hom besig hou. Dit is moeite, vermoeiend, moeilik, dit is 'n gejaag na wind, alles tevergeefs. En volgens die uitspraak aan die einde van ons teksvers, so ook die werk van die wetenskaplike van sy tyd, die wysheidsleraar.

Die Prediker was ook 'n wyse, en hy het gestaan in die tradisie van die wysheid. Sy strewe was lewenskunde en lewenskuns in die voiste en diepste sin van die woord. Die oorgelewerde wysheidsbeoefening is deur hom nie net bewaar en ongeskonde deurgegee nie. Hy het 'n meer omvattende program op die oog gehad met sy nadenke met sy ondersoek. Voor sy tyd was die bejefening van die wysheid beperk tot die waarneming en die vaslegging van die enkele ervaring. Daarvan kry ons in die boek Spreuke volop voorbeelde. Dit is dan ook die rede waarom ons somtyds spreuke vind wat eintlik die teenoorgestelde wil sê: "Antwoord 'n dwaas nie na sy sotheid nie, sodat jy nis ook net soos hy word nie". En direk in die vers daarna: "Antwoord 'n dwaas na sy sotheid sodat hy nie wys is in sy eie oë nie" (Spreuke $26: 4,5)$.

Die Prediker probeer uitstyg bo die enkele ervaring en die konklusie, die vaslegging daarvan. Hy streef na 'n geldige beoordeling van die totaal van die menselewe. Hy suek na die antwoord op die vraag: Wat is die sin van die lewe van die mens in d:e wêreld? Watter voordeel het die mens vir al sy moeite waarmee hy hom onder die son vermoei? Watter voordeel het hy wat werk daardeur dat hy hom vermuei? Wat bly daar oor vir die mens? Wat het die mens vir al sy arbeid en vir die strewe van sy hart? Wat bly oor?

Wat het die mens?

Niemand sou die Prediker daarvan kon beskuldig dat hy homself nie heelhartig toegewy het aan die ondersoek na hierdie lewensvrae nie. Hy het werklik gesoek na die sinvolle en die blywende in die menslike lewe. Hy getuig self dat hy sy hart daarop gerig het om met wysheid te ondersoek en na te speur alles wat onder die son gebeur. Hy wil weet, nadink en tot 'n slotsom kom. Sy waarneming van die maatskaplike lewe het hom gebring by die regswese, die sosiale en politieke verhoudinge van sy tyd, die arbeid van die mens om den brode en die vergader van besittings. Hy het self ook geëksperimenteer met die vrolikheid, die dwaasheid, die oorgawe aan werk, die versameling van besittings en met al die lewensgenietinge wat daar te vinde was. Hy het die wysheid teenour die dwaasheid in oënskou 
geneem, die gang van die tyd waargeneem en die verhouding van die mens teenoor God in die godsdiens bekyk.

En hy het tot 'n slotsom gekom. Sy slotsom oor die menslike lewe is: Alles tevergeefs en 'n gejaag na wind. Die hele menslike doen en late loop uit op 'n volledige niks. In die maatskaplike en politieke lewe het hy onreg en verdrukking gevind, naywer en hebsug. Van sy eie arbeid sê hy: „Toe het ek gekyk na al my werke wat my hande tot stand gebring het en al die moeitevolle arbeid wat ek verrig het, kyk, dit was alles tevergeefs en 'n gejaag na wind, en daar was geen voordeel onder die son nie." Van die wysheid self sê hy: „Wel het ek gesien dat die wysheid die voorkeur het bo die dwaasheid soos wat die lig die voorkeur het bo die duisternis. Maar ek het ook ingesien dat een en dieselfde lot hulle almal tref. Daarom het ek in my hart gesê: Dieselfde lot wat die dwaas tref sal my ook tref. Waarvoor was ek dan su buitengewoon wys? En ek het in my hart gespreek dat dit ook tevergeefs is". Van die menslike woorde in die godsdiens sê hy: „Soos daar baie drome is, so is daar ook nietige woorde in menigte."

Sy waarneming van die menslike lewe bring die Prediker ook by die omgrensdheid van die lewe. Inherent aan die menslike arbeid is die volslae sinloosheid daarvan. Reg en onreg, wysheid en dwaasheid, gesag en verset, alles loop ineen en die lewe laat hom nie netjies orden nie. Daar is nie lig en donker, verhewe en banaal, netjies afgebaken in verskillende vakke in die menslike lewe nie. Wat wel sinvol voorkom, stuit teen die onverbiddelike grens van die lewe self, die dood, die graf. Alles het sy bepaalde uur, alles gaan na een plek toe, alles is uit die stof en alles keer na die stof terug. „Weer het ek onder die son gesien dat die wedloop nie is vir die vinniges en die oorlog nie vir die helde nie; en ook die brood is nie vir die wyse of die rykdom vir die slimmes of ook guns vir die verstandiges nie; want tyd en lotgeval tref hulle almal".

In sy pragtige gedig aan die einde van sy boek teken die Prediker die afbraak van die mens wat op pad is na sy ewige huis, die graf. „Voordat die silwerdraad verwyder word en die goue oliekruik stukkend val en die kruik by die fontein gebreek word en die wiel stukkend val in die put en die stof na die aarde terug. keer soos dit gewees het en die gees na God terugkeer wat dit gegee het. Alles tevergeefs, sê die Prediker, dit is alles tevergeefs."

Watter voordeel is daar vir die mens; wat bly vir hom vor as hy sy toekoms nie ken nie, sy eie lot nie kan bepaal nie en op pad is na die graf? As van sy hoogste strewe gesê word dat dit geen voordeel bring nie, inteendeel dat dit nutteloos is? 
In ons tyd sal daar begrip wees vir die houding wat die Prediker self gemeen het om in te neem: die houding van lewenshaat en wanhoop. „Daarom het ek die lewe gehaat, want die werk wat onder die son gedoen word, het my mishaag, omdat alles tevergeefs is en 'n gejaag na wind ... Daarom het ek my begewe om my hart aan wanhoop oor te gee vanweë al die arbeid wat ek met moeite verrig het onder die son". Die weersin in die lewe is die uitvlug van die toekomsloses. Die wanhoop is ál antwoord wat oorbly wanneer alles tot niks verloop nie. In so 'n situasie lê daar beslis ook nie in boekemaak en in studie enige troos nie! Dit is 'n woord wat ons tyd goed kan verstaan, met sy baie uitsigloses, sy groot weersin in die lewe wat hom op soveel verskillende wyses in die samelewing van die twintigste eeu uit.

Maar laat ons eers iets anders vra: Wie is hierdie mens van wie die Prediker neerlê dat sy bestaan en bestemming ' $n$ volledige niks is? Kan dit die mens wees in verhouding tot God? Sê die Prediker dan niks oor God nie? En inderdaad, die Prediker praat oor God. Hy is nie 'n ateĩs soos hy al dikwels beskuldig is nie. Hy ken God en hy vrees God. Teenoor die absolute ydelheid van alles wat aards is staan vir die Prediker die absolute almag van God, en die mens is volkome en volledig van God afhanklik vir alles. Van God ontvang die mens nie net sy voedsel en sy drank, sy rykdom en sy skatte, sy lewensdae nie, maar ook die vermoë om dit te gebruik en te geniet. „Wie kan eet en wie kan geniet sonder Hom?" Wat Hy doen, bestaan vir ewig. Daar kan niks bygevoeg en daar kan niks van weggeneem word nie. Wie kan reguit makk wat Hy krom gemaak het? Die dag van vourspoed en die dag van onheil is altwee deur Hom gemaak. Hy is die Skepper van die lewe en $\mathrm{Hy}$ is die Gewer van die dood. Hy bepaal elke besonderheid van die menslike lewe. In sy absolute almàg heers en beheers $\mathrm{Hy}$, en sy gerig oor die mens lê voor. „Hy is in die hemel, jy op die aarde. Daarom moet juu woorde min wees." Daarom ook is sy werke nie te deurvors en te verstaan nie.

Weer 'n keer: Wie is die mens wat hom bevind tussen die twee uiterste grense van die absolute almag van God en die absolute nietigheid van alles wat aards is? Wat bly daar vir die mens oor?

Wanneer die Prediker praat oor God die Skepper, en oor die mens as sy skepsel, is daar by hom geen onsekerheid oor wie die mens is na wie se lewenssin en bestemming hy vra nie. Die Prediker praat van die mens ná die sondeval, dié mens wie se 
kennis van Gods geregtigheid en heiligheid geskonde is. „Kyk, net dit het ek uitgevind, dat God die mens reg gemaak het, maar hulle het baie slim planne gesoək." "Alles het Hy mooi gemaak op sy tyd, ook het hy die eeu in hulle hart gelè sonder dat die mens die werk wat God doen, van begin tot end, kan uitvind." Dit is die gevalle mens wat uitsigloos soek en nie vind nie, wat homself ' $n$ eensame wese bevind tussen die vertes van die almag van God en die nietigheid van alles wat aards is. Wat bly oor vir dié gevallene, dié eensame met sy weersin in die lewe en sy wanhoop?

Telkens verwyl die Prediker by die vreugde wat God in die lewe skenk. Hy beproef ' $n$ keer selfs die tradisionele opvatting van die wysheid, dat aardse geluk en die regte verhouding tot God saamval, die gedagte van vergelding volgens die mens se werke, maar sy waarneming van alles onder die son weerspreek daardie gedagte. Wat oorbly is vir die Prediker net die vreugde: bly wees, goed doen in die lewe, eet en drink en die goeie geniet by al sy moeitevolle arbeid; dit is 'n gawe van God. „Daarom het ek die vreugde geprys, dat daar niks beters is vir die mens onder die son nie as om te eet en te drink en hom te verheug en dat dit hom mag begelei by sy moeitevolle arbeid gedurende die dae van sy lewe wat God hom gee onder die son."

Teen die agtergrond van die Prediker se beskouing oor die menslike lewe is dit eintlik onvermydelik dat hierdie antwoord van hom op die lewensprobleem nie bevredig nie. Die vreugde van die hede, sy dit ook 'n hede wat deur God geskenk word, is uiteindelik ook vreugdeloos, want dit is deel van die absolute ydelheid en nietigheid van alles wat aards is. Dit is ook gejaag na wind, dit is ook tevergeefs.

Daarom: Wat bly oor vir die mens? Die graf. En of die aftakeling van die mens en sy dood daarna nou in alle naaktheid gestel word, ru, sonder versagting, en of 'n mens dit nou doen met 'n pragtige gedig soos wat die Prediker dit doen, dit kom daar nie op aan nie. Die mens wat die persoonlike verhouding tot God nie ken nie en wat die lewensprobleem wil beantwoord vanuit sy navorsing oor die menslike lewe, kom altyd dáár uit, by die grens van die mens, by die dood, by die graf. Daar is 'n grens. En teenoor die dood klink die lied van die vreugde hol en leeg.

Wat bly oor vir die mens as hy te staan kom voor die volledige niks tussen die vérheid van God en die ydelheid van die van God vervreemde menselewe? Vlug in die studeerkamer in, so gee ons teksvers te kenne, bring geen voleinding en geen vergenoegdheid nie. As alle weë vir die mens afgesny is, watter 
weg bly daar oor? As onder die son niks ourbly vir die mens nie, wat bly dan oor? As die mens met al sy middele tot sy beskikking die antwoord nie kan vind nie, waarvandaan moet die antwoord kom?

Ons kan dit ook anders sê: As die boek Prediker ons nie die antwoord op die probleem van die mens gee nie, wat gee die boek ons wel? En as ons nou kyk na die hantering van dié boek in die Nuwe Testament, dan kry ons ' $n$ insig in sy waarde wat ons miskien andersins nie sou hê nie. $\mathrm{Na}$ 'n woordelikse aanhaling uit die Prediker sal ons in die Nuwe Testament tevergeefs soek. Maar ons vind wel in die Nuwe Testament 'n aantal gedagtes wat deur die Prediker mede voorberei is, naamlik die onderwerping van die skepping aan die nietigheid (Rom. 8:20), die volstrekte sondigheid en verval van die mens (Rom. 3:10-12), die sekerheid van Gods gerig oor die menslike handeling (2 Kor. $5: 10$ ), die onvermoë van die mens om die wêreld rondom hom in sy totaliteit te deurvors en te ken (Joh. 3:8), die absolute verganklikneid van alle aardse dinge en die eis om vergenoegdheid (I Tim. 6:6, 7), die klem op ewewigtigheid en oorwoënheid in dic omgang met die medemens (Jak. 1:19).

Hieruit is dit al duidelik dat die Prediker in sy nugtere beskoulikheid 'n waarheid oor die mens uitgespreek het wat van God self kom. Die wysheid het van ouds af sy goddelike oorsprong bely en op eiesoortige wyse aanspraak gemaak op die gesag wat in die openbaring van God Self geleë is. Wanneer die Prediker die gang van die gevalle mens volg tot in die absolute niks, betuig hy vooruit die noodsaak van die ingryping van God in die menslike lewe. Van die mens af is daar geen weg na God toe nie, daar is net 'n weg van God na die mens. Die skepping ken die slawerny van die verganklikheid, die vrymaking kom van God. Die mens bewe in afwagting van die gerig, God voltrek die gerig. Die mens ken as die ondeurdringbare lewensgrens die dood. God deurbreek die grense van die dood en skep nuut.

Die smartkreet om die gevalle mens wat ons uit die boek van die Prediker hoor, dring vorentoe na die verlatenheid van die Mens van die kruis, Gods gerig wat eens en vir altyd die uitsigloosheid van die gevalle mens bevestig, om juis daarin versoening te skenk; die wonder van die geopende graf wat aan die toekomslose 'n toekoms gee. Deur middel van die Prediker het God die ellende van die mens wat in Jesus Christus tot sy volle verskriklike openbaring gebring het vantevore betuig, in Jesus Christus het Hy die antwoord gegee op die mens se lewensnood. Wat bly oor? 
$\mathrm{Na}$ die ellende, na die verlossing, die derte stuk van die Christelike geloof, die dankbaarheid. Dit is daar waar Paulus in die eerste Timothéüsbrief die Prediker se gedagtes oor die vergenoegdheid met die hede tuisbring. Dit is ook daar waar Jakobus die eis om ewewigtige besonnenheid in die omgang met dia naaste stel. Ná Jesus Christus staan Hy self tussen mens en mens. Na Sy opstanding is daar vir die gelowige nie een enkele sinnelose, leë dag meer nie. Boskemaak sal sonder einde bly hier onder die son. Studie sal deel bly van die moeilike tak wat God aan die mensekinders gegee het. Maar salig is die m气ns wat sy taak kan verrig op sy bepaalde tyd in die volheid van die tyd wat God geskenk het. Tussen die tye van die vleeswording van die Woord en die voleinding lê daar vir dié wat wag en hoop die vreugde; vreugde in die hede, vreugde in die arbeid, want God het in Jesus Christus naby ons gekom.

Amen.

Skriflesing: Pred. 11:9-12:14.

Rom. 8:18-39.

Liedere: Psalm 18:1, Gesang 106:4, 5, Gesang 92. 